\title{
Influence Analysis on Internal, External, and Religiousity Factors on Kafalah Service Fee Income of PT Penjaminan Jamkrindo Syariah (Period January 2015 - October 2018)
}

\author{
Annisa Fitri ${ }^{1}$, Roikhan Mochamad Aziz ${ }^{2}$, Acep R Jayaprawira ${ }^{3}$ \\ \{annisa.25fitrii@gmail.com ${ }^{1}$, hahslm.study@gmail.com², dynivity@gmail.com ${ }^{3}$ \} \\ Universitas Islam Negeri Syarif Hidayatullah, Jakarta Indonesia ${ }^{1}$, Universitas Islam Negeri Syarif \\ Hidayatullah, Jakarta Indonesia ${ }^{2}$, Universitas Trisakti, Indonesia ${ }^{3}$
}

\begin{abstract}
The purpose of this study is analyzing the influence of guarantee volume, claim quantity, promotion fee, inflation rate, SBIS, and firm charity to kafalah service fee income by using quantitative data method, the data used in this study is in numbers with multiple regression method using Ordinary Least Square (OLS). The result of this study shows that the variable of guarantee volume, claim quantity, SBIS partially have a significant influence of guarantee compensation income, while promotion fee and firm charity do not have any influence partially. The result of regression analysis is silmutaneusly attained that guarantee volume, claim quantity, promotion fee, inflation rate, SBIS and firm charity influence cooperatively the guarantee compensation income. The capability prediction of those six variables to guarantee compensation income obtained $99,53 \%$ and the balance is $0,47 \%$ is influence by another factors that's included in this model of study.
\end{abstract}

Keywords: Guarantee Compensation Income, Quantity Volume, Claim Quantity, Promotion Fee, Inflation Rate, SBIS, Quantitative Data.

\section{Introduction}

The development of real sector particularly business activity extremely influences the raising of economy's improvement in Indonesia. It has main function in maintaining Indonesian's economy and as national's backbone. It can be discerned from two indicators, that is employment and total of GDP (Gross Domestic Product).

Annual Report 2015 Ministry of Cooperatives Small and Medium Enterprises shows that total of the national businessman (Small and Medium Enterprises (SMES) and Big Enterprise) until year 2013 amounts to 57.900 .787 unit by total of the employment amounts to 117.681.244 people and GDP's total attained Rp 3.745.548 Billion. Total of the labors are decreasing attained 17,62\% during year 2008-2013 and GDP's total also shows the growth during $2008-2013$ reached $50,62 \%$. The data is quite explaining the development of business world move positively and increasing continuously.

The difficulty of financial access becomes the barrier for the businessman need quick fund. From the financial institutions, such as Bank, is against the uncertainty of debitor's quality and its business. Therefore, it is required risk mitigation step such as increasing 
interest rate and stretching credit's requirement, one of them is the requirement of high collateral. Guarantee institution can open new horizon for banking industry to compete and find the reality of new marketplace beneficially and learn risk management (1). Guarantee product is valuated relative more efficient than another intervention to Small and Medium Enterprises (SMES), such as credit program for certain target (Beck T 2010). (2)

The awareness of Indonesian, mostly moslem, to the necessity of using and utilizing product (goods and service) halal and thoyiban, so the role of the producer or the sharia's firms can be promising future alternative. Jamkrindo housing started the guarantee activity on sharia financial institution in 1997 by the cooperation of Muamalat Bank as the first sharia bank in Indonesia. It was the first cooperation on kafalah and becoming the inspiration of the MUI's National Sharia Fatwa Institution publication number 11/DSN-MUI/IV/2000 about Kafalah renewed with fatwa number 74/DSN-MUI///2009 about Sharia Guarantee. In 2003, the cooperation between Jamkrindo Housing and PT Bank Syariah Mandiri. Jamkrindo Housing took strategic step by establishing subsidiary, that is PT Jamkrindo Syariah pada on $19^{\text {th }}$ of October 2014 (3).

Born in 1 billion base capital deposited in 250 billion rupiah, PT Jamkrindo Syariah still develops until todays. Asset's total of PT Jamkrindo Syariah per $31^{\text {th }}$ of December 2016 amounts to Rp 354,76 Billion by the profit before the tax amounts to Rp. 10,86 Billion. The performance of PT Jamkrindo Syariah quite described the significant growth at least three years operating on PT Jamkrindo Syariah. In implementation, PT Jamkrindo Syariah was controlled by Sharia Comission Institution and as social responsibility and fulfilling Islam's command, PT Jamkrindo Syariah in 2016 and 2017 entrusted company charity to BAZNAS counted from company's profit.

In addition to internal and religiousity factors influence the growth of PT Jamkrindo Syariah as explained above, need to analyze wheether Indonesia's macro economy's indicator has significant influence on the development of PT Jamkrindo Syariah. One of macro economy's indicators becomes threat for national economy development is inflation rate. Fluctuating inflation rate can influence the productivity and profitability of the entrepreneur and the performance of NPL/NPF Banking and Financial Institution. Thus, the main business of PT Jamkrindo Syariah is trusting the customer's obligation or contractors (entrepreneurs) influenced from the inflation.

Central Bank plays important role to control the inflation. Bank of Indonesia uses the instruments in wider range of decreasing the inflation attacks in this country. The interest rate's bank policy is appropriated when inflation target cannot be reached. Another action to stretch monetary policy to increase the deposit's requirement for local currency's deposit or foreign currency in Indonesia's banks. Finally, Bank of Indonesia decreases the demand of foreign investor for Bank of Indonesia Certificate (SBI) by extending the period of SBI's proprietary's requirement from 1 month become 6 months, extending the due date from published SBI become 9 months and introducing the depositos commercial context to the longer due date (only available for the banks).

The understanding of Islamic economy always referes to whole Islamic concept or kafah. Kafah Islamic approach contains the revelation of iman, islam, and ihsan. These 3 discourses are strengthened by Islamic pillars, there are: 1) Creed , 2) Prayer, 3) Alms, 4) Fasting, 5) Pilgrimage. The result of these 3 pillars of Islam can be shown on Base Islamic economic theory consists of: 1) Oneness theory (tawhid), 2) worship theory, 3) public interest theory. The implementation of this main economic pillar is in line with the company development on Islamic perspective in Indonesia (Aziz, 2011)(4),(5),(6). Therefore, there is an approach to 
know the relation between company and the performance through internal factors external and religiousity.

From the background explained above, the author will research whether there is significant influence among internal factor, external factor, and religiousity factor on business development of PT Jamkrindo Syariah will be represented throughout kafalah service fee income rate. Therefore, from the considerations planned the author entitle this reserach is:

"INFLUENCE ANALYSIS ON INTERNAL, EXTERNAL, AND RELIGIOUSITY FACTORS ON KAFALAH SERVICE FEE INCOME OF PT PENJAMINAN JAMKRINDO SYARIAH (PERIOD JANUARY 2015 - OCTOBER 2018)”.

\section{Literature Reviews}

\subsection{Hahslm Theory}

Base thought from Hahslm approach is in Islam has genuine methodology standard different from existing approach today. Economy analysis brought about the authors scientifically in formal environment, such as university or research institution non formal like magazine publication periodically mostly use analysis tools. It is used to sharpen the analysis following the formulated analysis's purpose. But, the more complex the problem of life and economy, need to cultivate the means of worship to make into economy analysis purpose giving double benefit, that is world and hereafter (Aziz, 2006) (7),(8).

\subsection{Guarantee}

According to Deelen and Molenar (2004, p.11) (9) credit guarantee is defined as follows: "A credit guarantee is a financial product that a small entrepreneur can buy as a partial substitute for collateral. It is a promise by a guarantor to pay all or part of the loan if the borrower defaults". Guarantee activity has the principles, there are feasibility, complementary crediting (credit accesoir), substitute for collateral, temporary takeover of bad credit, subrogation receivables, third party involvement, and cooperation control. Those principles should be existing in guarantee as careful effort (prudent) because the risk of the big guarantee. Whereas, there is error/default by guarantee receiver so the claim payment cannot be carried out. On the contrary, if default is committed by the guaranteed so the guarantee company will pay the claim based on the guarantee contract agreed.

Kafalah service fee according to constitution Number 1 year 2016 about guarantee is amounts of money received by Sharia Guarantee Company and UUS from guaranteed in guarantee activity. Then, according to Fatwa DSN MUI Number 74 year 2009 about sharia guarantee that kafalah service fee is fee of using guarantee facility to assure the financial based on sharia principle (kafalah bil ujrah) (3).

There is no certain definition about guarantee volume or value based on the existing regulation up to now. Guarantee value used as measure value guaranteed by guarantor party as financial obligation guaranteed certain amount to guarantee receiver where guarantor party can guarantee amount to financial obligation guaranteed all or part of guaranteed's obligation based on provisions of guarantee principle approval letter/cooperation agreement/ guarantee certificate. Then, guarantee volume is accumulation of guarantee value in certain period or certain product segmentation. 
Fatwa DSN MUI Number 74/DSN-MUI/I/2009 (3) about Sharia Guarantee asserted that Kafalah service fee is fee on using guarantee facility to assure the financial based on sharia principle(kafalah bil ujrah). Kafalah service fee counted from guarantee value multiplied with Kafalah service fee rate stated in rupiah on kafalah certification. Therefore, the achievement of guarantee volume sharia guarantee company in certain period will intensely influence on kafalah service fee income. The bigger guarantee volume, the bigger kafalah service fee received by sharia guarantee company.

As explained in OJK (Financial Services Authority) Constitution Number. 2/POJK.05/2017 about the organization of Guarantee Institution Activity Chapter IV about Service Fee section 18 stated that amounts to guarantee service fee rates is determined based on claim ratio. It is a comparation between claim and guarantee service fee. Therefore, claim will influence on kafalah service fee rates' decision and kafalah service fee income received by guarantee company indirectly because of claim's descending and ascending will be calculated as base decision service fee rate. Guarantee company tend to increase service fee rate if claim ratio on guarantee is high based on empirical experience. On the contrary, if guaranteed risk assesed little and the claim ratio is little so the service fee rate is able to reduce it based on guarantee object risk rate assured. To convince the creditor of guarantee receiver, Guarantee Institution should have and determine the clearcriteria on claim (1).

Promotion is one of the elements in mixed marketing company used to notify, remind, and persuade the consumer about company's product (10). Promotion activity in company oriented in profit is extremely important and as benchmark company's success. Indeed, it is also felt by guarantee company where guarantee marketing business required promotion fee to support marketing activity in order to appropriate with expected. With the good and sustainability marketing strategy will bring the growth and company's sustainability to each risk and threat. Short definition from inflation is inclination from the costs to raise publicily and continuously in long period. The markup from one or two goods cannot be called inflation, except if the markup wider into (cause the markup) partly from other goods (11).

When inflation is getting higher, it will cause investment rate. It is caused by the raising inflation will lead to increase interest rate, in turn it will insist investment so that will cause decreasing investment (12). If investment flow is getting lower so the financial activity will be lower and the demand on guarantee will decrease. Therefore, inflation potentially influence the declining kafalah service fee on sharia guarantee company.

According to Bank of Indonesia Constitution Number. 12/11/2010, Bank of Indonesia Certificate is securities in Rupiah currency published by Bank of Indonesia as short term liabilities. Certificate of Bank of Indonesia (SBI) as one of monetary policy instrument used by Bank of Indonesia to have public market operation for receiving excess liquidity in market.

Ju'alah system is quite tantalizing with the service rate equalized to SBI discount becomes attraction for banking to save the fund in SBIS. It will also cause the decline money flow in production sector. As well as inflation and Bi rate, the profit of SBIS Margin will decrease financial of the bank to the customer so that the demand of guarantee will get lower. If SBIS can decrease inflation rate so the demand of guarantee will increase because of the raising of Bank's investment flow.

Alms is multidimensional worship, that is vertical (as fidelity unto Allah Swt by doing the obligation in al-Qur'an) and horizontal (as social care to fellow being and implementation of human's function as social creature cannot live alone). Based on these two aspects, the obligation to pay alms has function in each community life (Qardawi, 2002). 
The Alms' function in income's equity and property distribution will bring the community's welfare and economic growth. Therefore, the big potential of alms' acceptance with the moslem population in Indonesia and the good management become source of funds used by the middle to lower community level to increase their productivity. It will impact to the demand of guarantee because the cooperation process particularly required guarantee facility to ensure that the project goes well.

\section{Research Model, Hypotheses, and Methodology}

In this research, the author focuses on the dependent variable, that is kafalah service fee and its independent variable that focused on 3 categories. There are internal and external factors. The internal factors are guarantee volume, claim quantity, and promotion fee. The external factors are Inflation rate and SBIS and Religiousity factors consist of Company Charity Sharia Jamkrindo. This research is influence analysis research because the aim is researching/studying the influence between two variables, that is independent variable (guarantee volume, claim quantity, promotion fee, inflation rate, SBIS, and company charity) and the the dependent variable (kafalah service fee).

Data used in this research is monthly data (time series) from Sharia Jamkrindo Firm for the internal factors and religiousity and Bank of Indonesia for the external factor period January 2015 -October 2018.

In this research, the data is secondary data that acquired from the source indirectly. The external factor data is taken from Sharia Banking Statistic data from Bank of Indonesia's website. The data is monthly rate (quantitative) period January 2015 - October 2018. While the data of internal factor and religiousity are taken from the process of data submission to the Director of Finance, Human Resource and Public of Sharia Jamkrindo Firm and Business Director of Sharia Jamkrindo Company.

This research aims to analyze the influence of guarantee volume, claim quantity, promotion rate, SBIS, and company charity to kafalah service fee with quantitative data method, the data is numeric with multiple regression method using Ordinary Least Square (OLS) analysis by Eviews 8 program and Ms. Excel 2010.

Ordinary Least Square is an econometrics method that has independent variable is explanation variable and dependent varible, that is variable explained in linear equation. In OLS there is one dependent variable, whereas the amount of independent varible is more than one. If the free variable that is used only one called simple linear regression, then if the free variable used more than one called double/compound linear regression.

Hahslm theory also has equation that formulated altogether with the function of compound linear regression. In linear equation, there is $\mathrm{Y}$ dependent variable while in th equation there is $\mathrm{H}$ dependent variable. For the independent variable can be applied in regression equation and th which a function is constants in regression as protector of th, then error has e notation in regression and $h$ on th, and the main variable is $X_{1}, X_{2}, X_{n}$ on regression become $\mathrm{Sn}, \mathrm{Ln}, \mathrm{Mn}$ on th. $\mathrm{H}$ equation that is used as follows:

$\mathrm{H}=\mathrm{a}+\mathrm{b} 1 \mathrm{Sn}+\mathrm{b} 2 \mathrm{Ln}+\ldots+\mathrm{bnMn}_{\mathrm{H}}+\mathrm{h}$

$\mathrm{H}=\mathrm{a}+\mathrm{b} 1 \mathrm{Sn}+\mathrm{b}_{2} \mathrm{Ln}+\ldots+\mathrm{bnMn}_{\mathrm{H}}+\mathrm{h}$

Note: $\mathbf{H}=$ Huda/Guidance $(Y) \quad \mathbf{A}=$ Alif/Path $(\alpha) \mathbf{h}=$ Hanif/Straight (e) $\mathbf{S}=$ Sin/Human

(b1Xn) L = Lillah/Allah's (b2Xn) $\mathbf{M} \quad=$ Masjid/Worship (bnXn) 
The relation between the dependent and independent variable in this research can be formulated as follows: $\mathrm{H}$

$$
\mathbf{Y}=\mathrm{f}(\mathrm{X} 1, \mathrm{X} 2, \mathrm{X} 3, \mathrm{X} 4, \mathrm{X} 5, \mathrm{X} 6) \quad \mathbf{H}=\mathrm{f}(\mathrm{S} 1, \mathrm{~S} 2, \mathrm{~S} 3, \mathrm{~L} 1, \mathrm{~L} 2, \mathrm{M})
$$

While the econometrics model written:

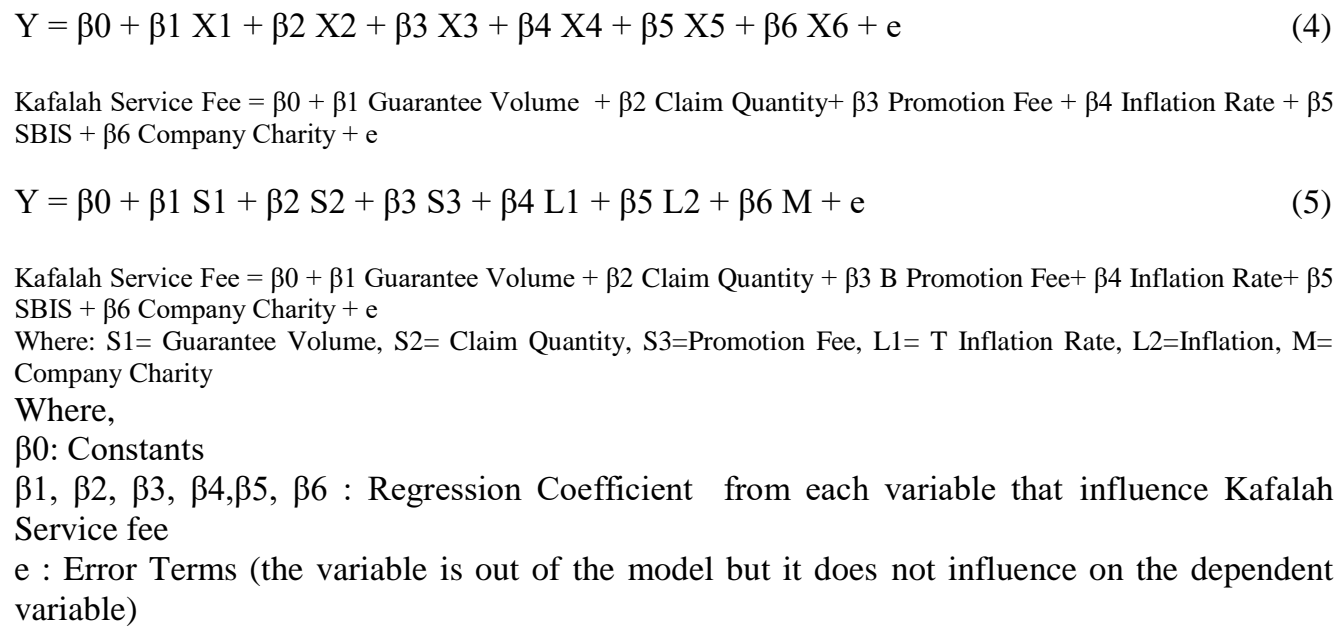

\subsection{Classic Assumption Test}

Classic Assumption Test used to detect whether there are normality, multicollinearity, heteroscedasticity, and autocorrelation. It is important to create the linear estimation not contradicts to minimum variant BLUE (Best Linier Unbiased Estimator), means the regression model does not contain any problems.

\section{Normality Test}

This normality test aims to test whether the regression model between dependent variable and independent variable or both of them have normal distribution or approximately normal. There are many types of normality test, as follows: lilliefors, kolmogorov smirnov, shapiro wilk and shapiro francia, skewness kurtosis, jarque bera, and etc.

\section{Multicollinearity Test}

Multicollinearity is the condition shows the correlation or strong connection between two free variables or a compound regression model. The regression models are linear regression, logistic regression, panel data regression, and cox regression.

3. Heteroscedasticity Test

Heteroscedasticity occurs if Ut variant is not constant or frequently changing during the change of independent variable value (Gujarati, 2006:146) (13).

4. Autocorrelation Test

Autocorrelation can be defined as "correlation among observation members in time order (as periodic line) or column (as circular data- by sector)" (Gujarati,2006:147) (13).

\subsection{Statistics Test}




\section{Partial Test (t-Test)}

According to Nachrowi (2008:17) t-test used to examine whether every free variable (independent) each partial or individual has significant influence to bound variable (dependent) on significant rate $0.05(5 \%)$ regarding as free variable of constant value. dengan menganggap variabel bebas bernilai konstan. The steps to take with t-test is examination/test (14).

2. Fisher Test (F-Test)

According to Nachrowi (2008:16) Fisher test (F-Test) used to find whether all free variables (independent) altogether influence to bound variable (dependent) on significant rate $0.05(5 \%)$. Testing all regression coefficient simultaneously is taken by F-test with testing/examining (14).

\section{Determination Coefficient Test}

According to Ajija (2011:34) (15) determination coefficient coefficient R2 (adjusted Rsquared). This determination coefficient shows the capability of regression line indicating $\mathrm{Y}$ bound variable can be explained by $\mathrm{X}$ free variable. Coefficient value R2 (adjusted R-squared) ranges from 0 until 1, the more close on 1 the better.

\subsection{Data Analysis}

Data used in this analysis is secondary data time series period January 2015 until October 2018. This research aims to analyze the influence between two variables, that is independent variable consistes of guarantee volume, claim quantity, promotion fee, inflation rate, SBIS, and company firm on dependent variable, that is kafalah service fee. In this research data is taken from monthly data PT Jamkrindo Syariah with data withdrawal permission and data of Bank of Indonesia can be accessed in www.bi.go.id.

The authors used multiple regression analysis Ordinary Least Square (OLS) which is the model used to estimate the regression function from regression sample function (Ajija, 2011:23) (15). Data tabulation with Eviews 9 program and software Ms. Excel 2010 to accelerate the result that state the variables. The analysis uses classic assumption test, statistics test, and determination test.

\subsection{Classic Assumption Test}

\section{Normality Test}

The Normality test shows that the data in this research is distributed normally. It can be seen from probability value attains $0.127199>0.05$. It can be inferred that the result of the regression distributes normally.so, the conclusion is $\mathrm{H} 0$ accepted and $\mathrm{H} 1$ rejected.

2. Multicollinearity Test

Based on the data, the Centered VIF value all independent variable is less than 10, asserted that there is no multicollinearity problem in this model and inferred $\mathrm{H} 0$ accepted and $\mathrm{H} 1$ rejected because:

From the result, it can be stated that Centered VIF value all independent variable is less than 10 , asserted that there is no multicollinearity problem in this model and inferred H0 accepted and $\mathrm{H} 1$ rejected because:

a. Centered VIF Value of Guarantee Volume by $6.072953<10$

b. Centered VIF Value of Claim Quantity by $8.367013<10$

c. Centered VIF Value of Claim Quantity by $8.367013<10$

d. Centered VIF Value of Inflation by $3.322021<10$ 
e. Centered VIF Value of SBIS by $6.271166<10$

f. Centered VIF Value of Charity by $2.737835<10$

3. Heteroscedasticity Test

From the result, it can be known that the probability value Chi-Square by 0.087 bigger than treusty rate by 0.05 so it is concluded the data is not heteroskedasticity and $\mathrm{H} 0$ accepted.

4. Autocorrelation Test

From the result, it is shown that probability value of Chi-Square 0.4613 is bigger than value 0.05 so it can be inferred that the data does not have autocorrelation problem and H0 accepted.

5. Statistics Test

The result of data tabulation or estimation result by Eviews 9 program uses multiplied linear regression method or Ordinary Least Square (OLS) as follows :

a. Partial Test (t-Test) :

1) Guarantee Volume: Probability value $0.0000<0.05$ by $t$ statistics value 36.72829 have significant influence positively on IJK. It means partially guarantee volume variable has positive influence significantly on kafalah service fee.

2) Claim Quantity: Probability Value $0.0097<0.05$ or statistics value by 2.718326 have significant influence positively on IJK. It means partially claim quantity variable has positive influence significantly on kafalah service fee. Promotion Fee : Probability Value . $0.2171>0.05$ (not influence on IJK) it means that partially promotion fee variable do not have any influence on kafalah service fee.

3) Inflation Rate: Probability Value $0.0419<0.05$ with the $t$ statistics value by 2.103393 ( have negative influence significantly on IJK). It means partially inflation variable has negative influence significantly on kafalah service fee.

4) SBIS : Probability Value $0.0018<0.05$ with t statistics value by 3.347179 (have positive influence significantly on IJK). It means partially SBIS has positive influence significantly on kafalah service fee.

5) Company Charity : Probability Value with $0.6452>0.05$ (not influence on IJK). it means that partially company charity variable do not have any influence on kafalah service fee.

b. Fisher Test (f-Test)

F-Test known as jointly test or model/Anova test, that is the test to see how all free variables altogether on bound variable. Probability value of F-statistics by $\mathbf{0 . 0 0 0 0}$ $<0.05$. so, simultaneously guarantee volume, claim quantity, promotion fee, inflation rate, SBIS, and company charity has significant influence on kafalah service fee.

c. Determination Coefficient Test

$\mathrm{R} 2$ determination coefficient used in this research is using adjusted value of $\mathrm{R} 2$ on evaluating best regression model. Because this research use more than one idependent variable. Determination coefficient test: Adjusted Value of R-Squared by 0.995467 shown that dependent variable variation of kafalah service fee altogether can be stated by dependent variable variation by $99 \%$. Then, the rest is $1 \%$ asserted by other variables that is not observed in this research. 


\section{Discussion}

\subsection{The influence of guarantee volume on kafalah service fee}

The result of regression shows that guarantee volume partially extremely dominates influence on kafalah service fee. The probability value $t$ statistics attain 0.0000 so it has significant value positively on kafalah service fee. The coefficient value amounts to 0.97 so every each guarantee volume increasing $1 \%$ will raise kafalah service fee $0.97 \%$.

The result of regression due to the practical of guarantee industry that kafalah service fer counted from guarantee value multiplied with kafalah service fee rate and stated in rupiah on kafalah certificate. Therefore, the achievement of guarantee volume of sharia guarantee company in certain period will intensely influence kafalah service fee income. The bigger guarantee volume, the bigger kafalah service fee received by sharia guarantee company.

\subsection{The influence on claim quantity on kafalah service fee income}

The result of regression on claim quantity variable shows that probability value $t$ statistics of claim quantity by 0.0097 smaller than signification rate $\alpha=5 \%$, it means claim quantity influence significantly on kafalah in PT Jamkrindo Syariah. With coefficient value amounts to 0.05 so every guarantee volume increasing $1 \%$ will raise kafalah service fee $0.05 \%$.

\subsection{The influence of promotion fee on kafalah service fee income}

Contradicts to existing theory where promotion fee should have positive impact on company income raising. But, the influence on promotion fee of PT Jamkrindo Syariah on kafalah service fee do not have significant influence. The result of regression on promotion fee variable shows probability value t-statistics by 0.2171 bigger than the level of $\alpha=5 \%$. It means the promotion fee variable do not influence on kafalah service fee. It is caused by several factors as follows:

1. Business development of PT Jamkrindo Syariah is not determined by the fee for promotion but another factor influence on potentiality of big sharia guarantee market or business synergy PT Jamkrindi Sharia as the prime of Jamkrindo housing have long role in guarantee industry.

2. The limit of this research is data used here extremely limited, it is unable to analyse the data and fulfill the expectation result well.

\subsection{The influence on inflation rate on Kafalah service fee income}

If inflation rate on kafalah service fee is increasing, it will cause the decline of investment flow. Because inflation will provide the raise of interest rate, in turn it will insist investment so the investment will decline (12). If the investment flow decreases, it means Bank hold the credit/financial up to community and the impact is tge demand on guarantee will decline. Therefore, inflation has potentiality to influence the decline of kafalah service fee in sharia guarantee company.

Assumption above due to the result of regression in this research which probability value t-statistics inflation rate variable amounts to $0.0419<0.05$. It means variable of inflation rate partially have significant influence negatively on kafalah service fee with coefgicient value regression of inflation rate variable by -0.264338 . It states that every increasing of inflation rate up to $1 \%$ it will decrease kafalah service fee by $0.26 \%$. 


\subsection{The influence of SBIS on Kafalah service fee income}

SBIS in certain condition will influence inflation rate. Based on Rahardjo dan Manurung's (2001) research stated that SBIS will decrease money flow in community (16). When inflation rate is extremely high and the economy is intensely stronger so the policy raises SBIS margin as solution to compress community demand on goods as causal factor of demand-pull-inflation so inflation can be pressed. Demand full-inflation is inflation occured because the raising of total demand (agregat demand) excessively while production (supply) cannot fulfill the demand level. According to Rahardjo dan Manurung's research (2001) can be inferred that influence SBIS on inflation rate is influencing positively (16).

When SBIS position is increasing, it shows that BI effort to decrease inflation rate in SBIS instrument so inflation target becomes decline again and interest rate adjust it. In this condition, it will imply in financial Bank growth and community's productivity will raise. Indeed, it will impact on the increasing of demand in guarantee financial facility or financial and the financial of kafalah service fee.

The assumption above supported by the result of regression test on SBIS variable where regression test on SBIS variable stated correctly on probability value t-statistics by $0.0018<$ 0.05 . It means that partially SBIS variable have significant influence positively on kafalah service fee with coefficient value by 0.620508 . It assumed that the increasing of SBIS up to $1 \%$, it will raise kafalah service fee up to $0.62 \%$.

\subsection{The influence of Company Charity on Kafalah service fee income}

The function of company charity in distribution of wealth carried the welfare of community and economy growth. Therefore, the potential of huge charity acceptance with the majority of moslem inhabitants in Indonesia and alms organized well as source of fund used by middle lower community level to increase the productivity. It will impact on the demand of guarantee facility particularly guarantee non financial.

Assumption above is not appropriate with the result of regression test on company charity variable where probability value t-statistics company charity variable $0.6452<0.05$ partially company charity do not influence on kafalah service fee. Company charity is still low and the influence is not massive so it is unable to influence of community welfare besides the organization is trusted to BAZNAS so the distribution is not monitored well by PT Jamkrindo Syariah.

\section{Conclusion and Suggestion}

\subsection{Conclusion}

Based on data analysis and discussion above, the author will conclude as follows:

1. In this research, the model is classic assumption test that partial test (t-test) shows that internal and external factors influence on kafalah service fee, which is guarantee volume variable in positive significant attains 0.0000 , the total of claim variable with positive significant occupies 0.0097 , variable of the inflation rate with negative significant reaches 0.0419 and SBIS with positive significant achieves 0.0018 . While promotion fee variable and company charity do not have significant influence on kafalah service fee income partially with probability value t statistics 0.2171 and 0.6452 . 
2. Simultaneously internal, external, and religiousity factors show the significant value with significant rate 0.0000 . it is stated that concomitantly guarantee volume variable, claim quantity, inflation rate, promotion fee, SBIS, and company charity have significant influence on kafalah service fee. R-Squared Adjusted value attains 0.995467 show that independent variable reach $99 \%$. Then, the rest is $1 \%$ explained by another variable that is not observed in this research.

\subsection{Suggestion}

Based on the conclusion above, it is stated that simultaneously internal, external, and religiousity factors on kafalah service fee eventhough partially the significant influence on kafalah service fee only comes from internal and external factors, therefore the researcher will give the suggestion as follows:

1. Grounded on the result of regression test show that guarantee volume variable dominates the influence on kafalah service fee with guarantee volume variable coefficient value attain 0.968230 so kafalah service fee income increases if PT Jamkrindo Syariah aggresively in promoting the products and expanding the market, in view of potential sharia guarantee market is quite large because the competitor in the same field is still low. Besides that, management of PT Jamkrindo Syariah can consider additional capital to raise the network of PT Jamkrindo Syariah in Indonesia.

2. Along with the increasing of guarantee performance PT Jamkrindo Syariah, promotion should get attention as part of marketing strategy. With the low promotion fee in PT Jamkrindo Syariah,in future the promotion fee should be raised regarding with technology approach in this millenial era.

3. In claim, the development of PT Jamkrindo Syariah in last three years still low. But the huge guarantee risk will getting bigger due to guarantee volume's raising, so the risk management will take the role in in analysis of guarantee by PT Jamkrindo Syariah.

4. The stability of economy is shown by the development of inflation rate and SBIS last two years enable sharia guarantee industry grow. Besides the building of infrastructure is extremely occured today. The investment flow ought to increase in real sector and imply to the raising of demand on guarantee facility.

5. Sharia guarantee industry is recently exist in last three years. With the limited data used, hopefully this research will be the beginning and inspiration for further research in sharia guarantee. In this research, expectably the scholars and students seeking the topic and new problem will get interest in the case of sharia guarantee industry and the development of industry will turn into applied scientific research.

\section{References}

1. Green A. Credit guarantee schemes for small enterprises: an effective instrument to promote private sector-led growth?. UNIDO, Programme Development and Technical Cooperation Division. 2003.

2. Beck T, Demirguc-Kunt A. Small and medium-size enterprises: Access to finance as a growth constraint. J Bank Financ. 2006;30(11):2931-43.

3. DSN-MUI. Himpunan Fatwa Dewan Syariah Nasional MUI Edisi Revisi Tahun 2006. Ciputat: CV Gaung Persada. 2016.

4. Aziz RM. New Paradigm on System Thinking. J Ekonotika. 2011; 
5. Aziz RM. Sinlammim: Kode Tuhan. Jakarta: Esa Alam. 2012.

6. Aziz RM. Teori H dalam Islam sebagai Wahyu dan Turats. J UIN Syarif Hidayatullah. 2015;82.

7. Aziz RM. Integrasi ilmu ekonomi islam: pendekatan filosofis dan simbolik. 2014.

8. Aziz RM. New Paradigma In On Sinlamim Kaffah In Islamic Economics. J Signifikan. 2010;9(2).

9. Deelen, Linda and KM. Guarantee Funds for Small Enterprises A manual for guarantee fund managers. 2004.

10. Rangkuti F. Strategi promosi yang kreatif dan analisis kasus. Gramedia Pustaka Utama. 2013.

11. Boediono. Ekonomi Moneter, Edisi 3. Yogyakarta: BPFE - UGM. 2000.

12. Nopirin. Ekonomi Moneter, Buku I dan II. Yogyakarta: BPFE - UGM. 2000.

13. Gujarati DN. Dasar-dasar Ekonometrika jilid 2." Jakarta: Penerbit. 2006.

14. Nachrowi ND, Usman H. Pendekatan Populer dan Praktis Ekonometrika Untuk Analisis Ekonomi dan Keuangan. Jakarta: FEUI. 2008.

15. Ajija SR, Sari DW, Setianto RH, Primanti MR. Cara cerdas menguasai Eviews. Jakarta: Salemba Empat. 2011.

16. Rahardja P, Manurung M. Teori Ekonomi Makro Suatu Pengantar. Lemb Penerbit Fak Ekon Univ Indones. 2001; 